\title{
Iron supplementation enhances response to high doses of recombinant human erythropoietin in preterm infants
}

\author{
Virgilio P Carnielli, Rosalia Da Riol, Giovanni Montini
}

\begin{abstract}
Aims-To determine whether iron supplementation would enhance erythropoiesis in preterm infants treated with high doses of human recombinant erythropoietin (r-HuEPO).

Methods-Sixty three preterm infants were randomly allocated at birth to one of three groups to receive: r-HuEPO alone, $1200 \mathrm{IU} / \mathrm{kg} /$ week (EPO); or r-HuEPO and iron, $1200 \mathrm{IU} / \mathrm{kg} /$ week of $\mathrm{r}-\mathrm{HuEPO}$ plus $20 \mathrm{mg} / \mathrm{kg} /$ week of intravenous iron (EPO+iron); or to serve as controls. All three groups received blood transfusions according to uniform guidelines.

Results-Infants in the EPO+iron group needed fewer transfusions than controlsmean (95\% CI) $1.0(0.28-1.18)$ vs 2.9 (1.843.88 ) and received lower volumes of blood-mean (95\% CI) 16.7 (4.9-28.6) vs $44.4(29.0-59.7) \mathrm{ml} / \mathrm{kg}$. The EPO group also needed lower volumes of blood than the controls-mean (95\% CI) 20.1 (6.2$34.2)$ vs $44.4(29.0-59.7) \mathrm{ml} / \mathrm{kg}$, but the same number of transfusions, $1.3(0.54$ 2.06) vs 2.9 (1.84-3.88). Reticulocyte and haematocrit values from postnatal weeks 5 to 8 were higher in the EPO+iron than in the EPO group, and both groups had higher values than the controls. Mean (SEM) plasma ferritin was lower in the EPO group-65 (55) $\mu \mathrm{g} / 1$ than in the EPO+iron group 780 (182) $\mu \mathrm{g} / 1$, and 561 (228) $\mu \mathrm{g} / 1$ in the control infants.

Conclusions-Early administration of high doses of r-HuEPO with iron supplements significantly reduced the need for blood transfusion. Intravenous iron (20 $\mathrm{mg} / \mathrm{kg} /$ week in conjunction with $\mathrm{r}-\mathrm{HuEPO}$ yielded a higher reticulocyte count and haematocrit concentration after the forth week of life than r-HuEPO alone. Infants treated with r-HuEPO alone showed signs of reduced iron stores.
\end{abstract}

(Arch Dis Child Fetal Neonatal Ed 1998;79:F44-F48)

Department of

Paediatrics

University of Padova

Via Giustiniani 3

35128 Padova

Italy

V P Carnielli

R Da Riol

G Montini

Correspondence to:

Dr Virgilio P Carnielli.

Email:

carnielli@child.pedi.unipd.it

Accepted 18 January 1998 for blood transfusions in preterm infants. ${ }^{9-21}$ Studies of r-HuEPO treatment show that this hormone stimulates reticulocyte response in a dose dependent manner, but there are few data on the role of supplemental iron. ${ }^{20}$ Different iron supplements are given in all randomised published r-HuEPO trials, starting at different postnatal ages. ${ }^{9-20}$ In our previous study ${ }^{13}$ we administered high doses of intravenous $\mathrm{r}-\mathrm{HuEPO}$ and $20 \mathrm{mg} / \mathrm{kg}$ of intravenous iron once a week from day 2 of life until discharge. Control preterm infants were not given either r-HuEPO or iron. In the present study we hypothesised that treating preterm infants with high doses of $r-H u E P O$ would produce a marginal iron deficiency, so that iron supplementation would enhance erythropoiesis.

Low birthweight preterm infants were randomly allocated to receive $\mathrm{r}$-HuEPO alone, r-HuEPO plus iron, or to serve as controls: to confirm in a larger series of infants the marked reduction in blood transfusions found in our previous study ${ }^{13}$; to see whether similar results could be achieved without iron supplementation; and to evaluate if the infants treated with high doses of r-HuEPO alone would develop signs of reduced iron stores.

\section{Methods}

Sixty three consecutive preterm infants, admitted to our neonatal intensive care unit after parental consent had been obtained, were studied. Inclusion criteria were: birthweight $\leqslant 1750 \mathrm{~g}$ and gestational age $\leqslant 32$ weeks. Infants with disabilities, congenital heart defects or congenital infections, severe perinatal asphyxia (Apgar score at 5 minutes $<5$ ) and other diseases not strictly related to prematurity, were excluded. Infants meeting the inclusion criteria were randomly allocated to receive from the second day to the eighth week of life (or hospital discharge): (i) $400 \mathrm{IU} \mathrm{rHuEPO} / \mathrm{kg}$ three times a week (Eprex, Cilag, Italy) +20 $\mathrm{mg} / \mathrm{kg} /$ week of intravenous iron (Ferrum, Hausmann SA San Gallo, Switzerland) (EPO+iron, $\mathrm{n}=22$ ); (ii) $400 \mathrm{IU}$ of $\mathrm{rHuEPO} / \mathrm{kg}$ three times a week (EPO, $n=20)$; or (iii) to serve as controls $(n=21)$. rHuEPO was administered intravenously if the patient had an intravenous line and then continued subcutaneously at the same dose. Iron was administered once a week as a continuous intravenous infusion over 3 hours under the direct supervision of one of the investigators (RD). All infants were fed the same preterm formula and they received about $80 \mu \mathrm{g} / \mathrm{kg}$ of folic acid and $25 \mathrm{IU} /$ day of vitamin $\mathrm{E}$ during the study period 
Table 1 Clinical data at birth and during study period

\begin{tabular}{|c|c|c|c|}
\hline & $p$ Value & $E P O(n=20)$ & EPO+iron $(n=22)$ \\
\hline Birthweight (kg) & $1.33(0.28)(1.19-1.45)$ & $1.27(0.28)(1.14-1.41)$ & $1.32(0.28)(1.19-1.44)$ \\
\hline Gestational age (weeks) & $29.8(2.2)(28.8-30.8)$ & $29.3(2.0)(28.4-30.4)$ & $29.7(1.6)(28.9-30.3)$ \\
\hline Standard deviation score of birthweight & $-1.1(0.7)(-1.4--0.7)$ & $-0.9(0.8)(-2.3--0.5)$ & $-0.9(0.7)(-1.4--0.7)$ \\
\hline Apgar score at $5 \mathrm{mins}$ & $6.9(1.3)(6.6-7.4)$ & $7.0(1.5)(6.6-7.4)$ & $7.1(1.2)(6.2-7.3)$ \\
\hline Systolic blood pressure ${ }^{\star}(\mathrm{mm} \mathrm{Hg})$ & $70.3(10.2)(68.2-72.1)$ & $70.2(7.8)(68.8-72.3)$ & $72.3(8.7)(68.8-72.1)$ \\
\hline Diastolic blood pressure ${ }^{\star}(\mathrm{mm} \mathrm{Hg})$ & $41.2(6.3)(40.4-42.9)$ & $42.4(5.6)(42.0-44.5)$ & $42.8(4.9)(41.8-43.8)$ \\
\hline Days on ventilator & $12(14)(5.0-18.6)$ & $13(18)(3.7-18.1)$ & $9(13)(3.7-17.4)$ \\
\hline Days of oxygen & $18(19)(9.3-26.9)$ & $16(19)(5.5-22.7)$ & $11(14)(3.3-19.5)$ \\
\hline Days of IV & $19(14)(12.6-21.0)$ & $18(15)(11.8-19.3)$ & $17(12)(11.1-20.4)$ \\
\hline Days on antibiotics & $8.3(7.4)(4.9-11.6)$ & $8.3(7.9)(4.5-12.1)$ & $8.0(4.6)(5.3-11.7)$ \\
\hline Days in hospital & $56(30)(42.5-70.0)$ & $58(39)(38.0-63.6)$ & $45(23)(34.8-68.2)$ \\
\hline Days to regain birthweight & $13(6)(10.0-16.1)$ & $14(6)(10.9-16.4)$ & $17(6)(13.9-19.5)$ \\
\hline Weight gain from birth to 8 weeks ( $\mathrm{g} / \mathrm{kg} /$ day) & $9.5(2.9)(7.9-11.0)$ & $10.1(1.8)(10.9-16.4)$ & $8.7(3.1)(7.3-10.2)$ \\
\hline
\end{tabular}

Data are give as group mean (SD) and (95\% CI).

${ }^{\star}$ mean values $(\mathrm{SD})(95 \% \mathrm{CI})$ of the averaged weekly weight gains of each patient during the study.

There are no significant differences among groups.

as is customary in our intensive care unit. No oral iron supplements were given during the study period and the preterm formula contained $0.6 \mathrm{mg}$ of iron per $100 \mathrm{ml}$ ready to feed. Clinical data are reported in table 1.

$\mathrm{R}-\mathrm{HuEPO}$ and iron were administered to the patients by one investigator (RD); the attending physician, who judged the need for blood

Table 2 Incidence of the common diseases of prematurity

\begin{tabular}{llll}
\hline & $\begin{array}{l}\text { Controls } \\
(n=21)\end{array}$ & EPO (n=20) & $\begin{array}{l}\text { EPO+iron } \\
(n=22)\end{array}$ \\
\hline $\begin{array}{l}\text { Respiratory distress syndrome } \\
\text { Bronchopulmonary dysplasia }\end{array}$ & $13(61 \%)$ & $10(50 \%)$ & $11(50 \%)$ \\
Patent ductus arteriosus & $7(33 \%)$ & $6(30 \%)$ & $5(22 \%)$ \\
Intracranial hemorrhage & $9(43 \%)$ & $11(55 \%)$ & $7(32 \%)$ \\
Sepsis & $3(14 \%)$ & $2(10 \%)$ & $2(9 \%)$ \\
Retinopathy of prematurity & $2(10 \%)$ & $3(15 \%)$ & $0(0 \%)$ \\
\hline
\end{tabular}

There are no significant differences among groups.

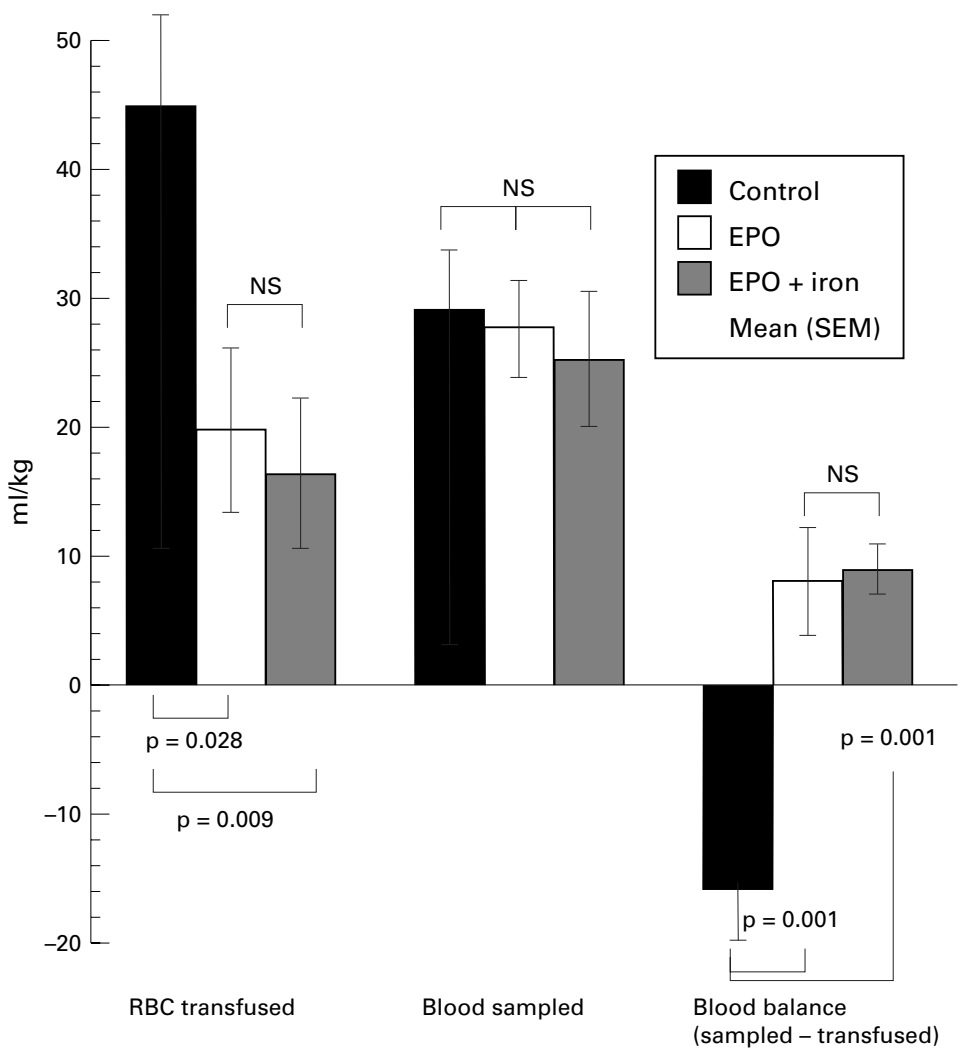

Figure 1 Blood balance in preterm infants treated with EPO+ iron, EPO alone, and in controls. Left hand columns represent volume of red blood cells transfused, central columns indicate volume of blood sampled for laboratory testing, and right hand columns show difference between blood sampled and transfused. transfusions, was blinded to the infant's treatment group. Infants received transfusions of packed cells $(10 \mathrm{ml} / \mathrm{kg})$ during the first week of life if their peripheral haematocrit (heel stick) was below $42 \%$ or $36 \%$, depending on whether the patient was receiving supplemental oxygen. After the first week of life, indications for transfusion were haematocrit below 36\% for oxygen dependent patients and $32 \%$ if in room air. Haematocrit concentrations for red blood cell transfusions for blood obtained from venepuncture or arterial samples were $4 \%$ lower than the above mentioned values $(38 \%$ and $32 \%$ for oxygen dependent and nonoxygen dependent patients in the first week and $32 \%$ and $28 \%$ thereafter). All infants received dedicated units of red blood cells.

Blood samples were obtained from the patients weekly for determination of haemoglobin, haematocrit, red cell indices (mean cellular volume (MCV), mean cellular haemoglobin $(\mathrm{MCH})$, mean cellular haemoglobin concentration (MCHC)), white cells with differential counts, thrombocytes, and reticulocyte count. Plasma ferritin concentrations were determined every two weeks from week 4, using a fluorimetric enzyme immunoassay (Baxter Diagnostics Inc. Deerfield, ILL, USA). Routine biochemical determinations including urea, creatinine, uric acid, cholesterol, triglycerides, total proteins, albumin, bilirubin and iron were also obtained weekly. Blood samples were taken before iron administration. The following data were recorded during the treatment period: heart rate; respiratory rate (hourly); blood pressure (twice a day); evidence of apnoeas, brady/tachycardias; transfusion requirements; blood volume sampled, volume of packed red cells transfused; weight gain; energy intake (daily), as described before. ${ }^{13}$

Results are expressed as mean and standard deviation (SD) or mean and standard error (SE), as appropriate. Statistical comparison between groups analysis was accomplished using ANOVA, and the $\chi^{2}$ test. To avoid skew distributions, such as the number of blood transfusions or number of days in hospital, the logarithms of the original data values were used for analysis. For the haematological picture, the mean of each subject was calculated and the means were analysed as if raw data. 

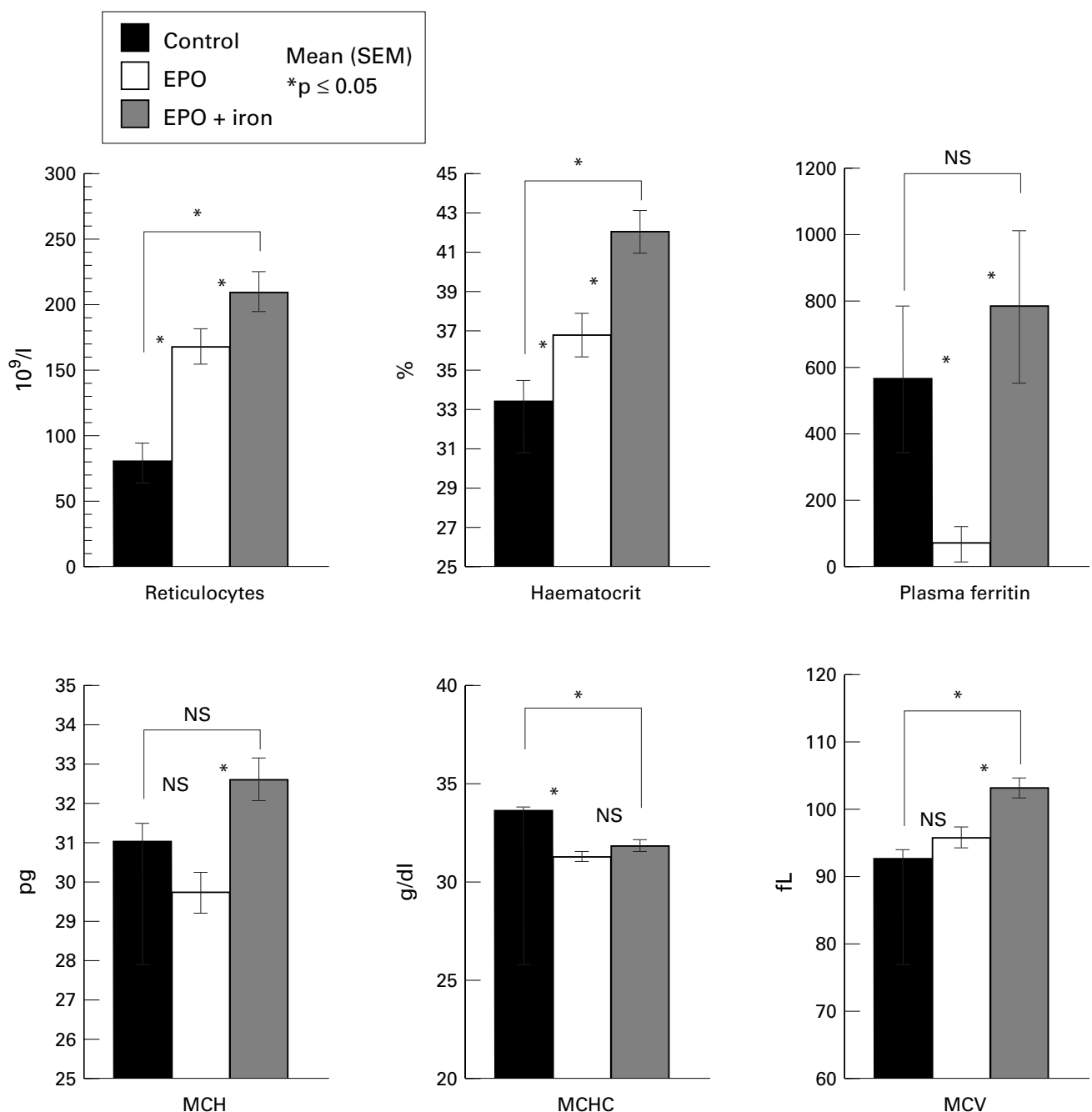

Figure 2 Reticulocytes, haematocrit, plasma ferritin, mean cellular haemoglobin (MCH) mean cellular haemoglobin concentration $(M C H C)$, and mean cellular volume $(M C V)$ in three groups of preterm infants during the second month of life: $E P O+$ iron $(n=10) ; E P O$ alone $(n=11)$, and controls $(n=10) .{ }^{\star} p<0.005$.

\section{Results}

Clinical characteristics at birth and during the hospital stay are shown in table 1 . The diseases of prematurity were remarkably similar among the study groups (table 2). Heart rate, respiratory rate, number of episodes of apnoea, and other clinical variables were no different. In spite of similar clinical characteristics and severity of the illnesses, the infants who were assigned to the EPO and EPO+iron groups required lower volumes of blood despite similar losses from phlebotomies (fig 1). The mean number of blood transfusions was 2.9 (95\% CI $1.84-3.88), 1.3(0.54-2.06)$, and $1.0(0.28$ 1.18 ) in the control, EPO, and EPO+iron groups, respectively (control vs EPO, $\mathrm{p}=0.065$ and control vs EPO+iron, $\mathrm{p}=0.035$ ). Figure 2 shows the mean values of selected haematological variables and plasma ferritin from study weeks 5 to 8 .

Reticulocytes were increased in the treated groups compared with the controls. The EPO+iron group had significantly higher reticulocytes than the EPO group $(\mathrm{p}=0.047)$. No significant differences were found during the first 4 weeks of life (data not shown). Infants treated with EPO+iron also had signifi- cantly higher haematocrit, haemoglobin, MCV and $\mathrm{MCH}$ than the other groups (fig 2). Plasma ferritin was the same in the control and the EPO+iron groups; both groups exhibited significantly higher values than the EPO group. Platelet, white cell, and neutrophyl counts were the same. No differences were found for several biochemical variables including plasma urea, creatinine, uric acid, cholesterol, triglycerides, total proteins, albumin, bilirubin and total iron (data not shown).

\section{Discussion}

The ultimate end point for any study using $\mathrm{r}-\mathrm{HuEPO}$ in preterm infants must be, in our view, a reduction in the number of blood transfusions and of donor exposures. We confirmed in a larger number of subjects our previous finding ${ }^{13}$ that high doses of r-HuEPO stimulate erythropoiesis and reduce the number of blood transfusions in preterm infants. Few studies, as far as we are aware, have clearly addressed this issue. In a double blind study using $200 \mathrm{IU} / \mathrm{kg} /$ week intravenously from week 3 of age, there was no significant difference in transfusion between the r-HuEPO and the placebo groups. ${ }^{22}$ In a second double blind study using 
similar doses, but with treatment beginning after the first week, there was a $41 \%$ reduction in the number of transfusions required, although this did not reach significance. ${ }^{14}$ Soubasi et $\mathrm{al}^{23}{ }^{23}$ using $300 \mathrm{IU} / \mathrm{kg} /$ week, showed that the need for transfusion was significantly reduced only in "uncomplicated infants"those without severe respiratory distress syndrome or sepsis $(0.37$ (0.74) vs 1.12 (0.83), in treated $v s$ non-treated infants). No difference was found, however, in the "complicated infants" who received 8.25 (5) (treated) vs 7.75 (3.7) (not treated) transfusions. The European Multicentre Erythropoietin Study Group ${ }^{16}$ has recently reported on the efficacy of r-HuEPO (750 IU kg/week) in reducing the need for blood transfusion in a large number of infants. The difference in blood transfusions between groups, although significant, was relatively modest, from a clinical point of view. ${ }^{24}$ $\mathrm{r}$-HuEPO treatment reduced the transfusion need by only 0.38 transfusion per patient. Similarly clinically modest results were found in a recent study in the USA. ${ }^{18}$ These authors used $500 \mathrm{IU} / \mathrm{kg} /$ week and found a modest although significant reduction of 0.5 transfusions per patient (1.1 (1.5) vs 1.6 (1.7) r-HuEPO vs controls, respectively).

Although differences in study design make comparisons rather difficult, blood losses from phlebotomies were not markedly different between our and the two above mentioned studies. ${ }^{16}{ }^{18}$ Furthermore, although differences exist between the patient populations, we are convinced that the better outcome of our study can best be explained by the higher doses of r-HuEPO and by the timing of its administration. In effect, what we need in these very young patients, is a prompt and sustained stimulation of erythropoiesis, to expand rapidly the red blood cell mass. This result can be accomplished only with very high doses of the recombinant hormone. The clinical experience derived from end stage renal failure ${ }^{25}$ used to establish the initial doses, has a very different theoretical background (chronic anaemia) and clinical need (chronic population).

The second major finding of our study is that iron supplementation is associated with enhanced erythropoiesis (higher reticulocytes and haematotocrit values) compared with infants treated with r-HuEPO alone. These infants developed signs of reduced iron stores as early as 5-6 weeks of age. Supplemental iron in nearly all published r-HuEPO data was given orally and in most cases it ranged from 2 to $8 \mathrm{mg} / \mathrm{kg} /$ day. In only one study were higher doses (18 mg/day) given. ${ }^{26}$ We chose the intravenous route and the dose of $20 \mathrm{mg} / \mathrm{kg}$ once a week that corresponds to $3 \mathrm{mg} / \mathrm{kg} /$ day. The rationale for such a dose was to minimise the risk that a marginal iron deficiency would diminish the clinical response to the high doses of $r-H u E P O$. In studies where iron supplementation and doses of r-HuEPO were far lower than ours, the patients developed low serum concentrations of iron or ferritin. ${ }^{11} 12232728$ Ohls $e a^{19}$ administered iron intravenously at 1 $\mathrm{mg} / \mathrm{kg} /$ day in total parenteral nutrition solution. Serum ferritin in their patients was meas- ured after 10 days of intravenous administration of iron dextran and was 225 (42) $\mathrm{ng} / \mathrm{ml}$. Interestingly, in adults iron deficient erythropoiesis develops even in iron replete subjects. ${ }^{29}$ Our data are consistent with previous observations that iron stores are critical to the rate of red blood cells produced. ${ }^{30}$ The development of iron deficiency occurs in stages: first, body iron stores are depleted, reflected by a fall in serum ferritin; then transferrin saturation becomes abnormal; and finally anaemia develops. Red blood cells with a low MCHC are usually not seen until this final stage. ${ }^{31}{ }^{32}$ In our study preterm infants receiving r-HuEPO alone exhibited after the fourth week of life lower plasma ferritin, lower reticulocytes, and lower haematocrit than those receiving r-HuEPO+iron (fig 2). Thus our data clearly show the need for iron supplementation in patients treated with r-HuEPO. In all infants the umbilical cords were clamped immediately at birth and no placental transfusion was allowed. Under these conditions the infants in the study might have become more rapidly depleted of their iron stores (especially those assigned to the EPO treated group) than if they had received additional blood at birth. ${ }^{33}{ }^{34}$ The MCV was also lower in the EPO group, although we did not find significant differences in the MCHC. Future studies examining the serum concentrations of soluble transferrin receptors ${ }^{35}{ }^{36}$ and the proportion of red blood cells containing a low concentration of haemoglobin ${ }^{28}{ }^{29} 37$ will identify earlier signs of iron deficiency. Our data clearly show that preterm infants receiving high doses of $r-H u E P O$ need generous iron supplements. Whether large oral doses would be as effective as our intravenous regimen, or whether similar effects could be achieved by a lower intravenous dose, remain to be evaluated. A recent study ${ }^{20}$ has shown that high doses of both oral $(12 \mathrm{mg} / \mathrm{kg} /$ day) and intravenous ( $6 \mathrm{mg} / \mathrm{kg} /$ week) iron seem to supply sufficient iron for erythropoiesis in stable infants, but storage iron becomes depleted in the oral group. An intravenous supplementation of iron in rHuEPO treated preterm infants is therefore recomended, especially if serum ferritin concentrations are low. Starting iron supplements later in life could have the advantage of minimising the peroxidative damage which may be enhanced by iron administration. ${ }^{38}$ The number of infants we studied is clearly too small to demonstrate any effect of intravenous iron in terms of potentiation of infection, nor this was one of our study objectives. However, we did not find any differences in the incidence of infections nor in the diseases of prematurity in which oxygen radicals are thought to have a role (table 2). ${ }^{38}$ We choose not to study a group of infants receiving iron alone. In theory, iron alone could stimulate erythropoiesis by increasing serum iron concentration, but we felt that because of the paucity of information on intravenous iron in preterm infants, this treatment was not justified without the associated benefits of the r-HuEPO treatment. Furthermore, we believe that iron supplementation is not justified in an allegedly iron replete group such as a group of 
infants receiving multiple blood transfusions during the first 2 months of life.

In conclusion, we found that early administration of high doses r-HuEPO to preterm infants with iron supplements significantly reduces the need for blood transfusions, iron supplements in conjunction with r-HuEPO yield higher reticulocytes and haematocrit after the fourth week of life, and infants treated with $\mathrm{r}-\mathrm{HuEPO}$ alone show signs of iron deficiency. We emphasise that further studies are needed on the safety, timing, and efficacy of iron supplements during r-HuEPO treatment.

1 Strauss RG. Erythropoietin and neonatal anemia. $N$ Engl $\mathcal{F}$ Med 1994;33:1227-8.

2 Strauss RG. Transfusion therapy in neonates. $A m \mathcal{F}$ Dis Child 1991;145:904-11.

3 Shannon KM. Anemia of prematurity: progress and prospects. Am f Pediatr Hematol 1990;12:14-20.

4 Shannon K, Keith J, Mentzer B, Phibbs R. Recombinant erythropoietin in anemia of prematurity: five years later. Pediatrics 1993;92:614-17.

5 Stockman JA, Garcia JF, Oski FA. The anemia of prematurity: Factors governing the erythropoietin response. $N$ Engl rity: Factors governing the
$f$ Med $1977 ; 296: 647-50$.

6 Emmerson AJB, Westwood NB, Rackham RA, Stern CMM, Pearson TC. Erythropoietin responsive progenitors in Pearson TC. Erythropoietin responsive progenitors
anaemia of prematurity. Arch Dis Child 1991;66:273-5.

7 anaemia of prematurity. Arch Dis Child 1991;66:273-5. Arch Dis Child 1993;69:273-5.

8 Rhondeau SM, Christensen RD, Ross MP, Rothstein G, Simmons MA. Responsiveness to recombinant human erythropoietin of marrow erythroid progenitors from infants with the "anemia of prematurity". $f$ Pediat 1988;112:935-40.

9 Beck D, Masserey E, Meyer M, Calame A. Weekly intravenous asdministration of recombinant human erythropoietin in infants with the anaemia of prematurity. Eur $f$ Pediatr 1991;150:767-72.

10 Obladen M, Maier R, Segerer H, et al. Efficacy and safety of recombinant human erythropoietin to prevent the anae-
mias of prematurity. Contrib Nephrol 1991;88:314-26.

11 Shannon KM, Mentzer WC, Abels RI, et al. Enhancement of erythropoiesis by recombinant human erythropoietin in low birth weight infants: a pilot study. $\mathcal{f}$ Pediatr low birth weigh

12 Halperin DS, Felix M, Wacker P, Lacourt G, Babel JF, Wyss M. Recombinant human erythropoietin in the treatment
of infants with anaemia of prematurity. Eur $\mathcal{F}$ Pediatr of infants with

13 Carnielli VP, Montini G, DaRiol R, Dall'Amico R, Cantarutti F. Effect of high dose of human recombinan erythropoietin on the need for blood transfusions in preterm infants. F Pediatr 1992;121:98-102

14 Emmerson AJB, Coles HJ, Stern MM, Pearson TC. Double blind trial on recombinant human erythropoietin in preterm infants. Arch Dis Child 1993;68:291-6.

15 Messer J, Haddad J, Donato L, Astruc D, Matis J. Early treatment of premature infants with recombinant human erythropoietin. Pediatrics 1993;92:519-23.

16 Maier RF, Obladen M, Scigalla P, et al. The effect of epoetin beta (recombinant human erythropoietin) on the need for transfusion in very-low-birth-weight infants. $N$ Engl f Med 1994;330: 1173-88.

17 Gallagher PG, Ehrenkranz RA. Erythropoietin therapy for anemia of prematurity. Clin Perinatol 1993;20:169-91.
18 Shannon KM, Keith JFI, Mentzer WC, et al. Recombinant human erythropoietin stimulates erythropoiesis and rehuman erythropoietin stimulates erythropoiesis and reduce erythrocyte transfusions in very

19 Ohls RK, Veerman MW, Christensen RD. Pharmacokinetics and effectiveness of recombinant erythropoietin administered to preterm infants by continous infusion in total parenteral nutrition solution. F Pediatr 1996;128:518-23.

20 Meyer MP, Haworth C, Meyer JH, Cammerford A. A comparison of oral and intravenous iron supplementation in preterm infants receiving recombinant erythropoietin. $\mathcal{F}$ Pediatr 1996;129:258-63.

21 Maier RF, Obladen M, Messinger D, Wardrop CAJ. Factors related to transfusion in very low birthweight infants treated with erythropoietin. Arch Dis Child 1996;74:F182F6.

22 Shannon KM, Mentzer WC, Abels RI, et al. Recombinant human erythropoietin in the anemia of prematurity: results of a placebo-controlled pilot study. $f$ Pediatr 1991;118:949-55.

23 Soubasi V, Kremenopoulos G, Diamandi E, Tsantali C, Tsakiris D. In which neonates does early recombinant human erythropoietin treatment prevent anemia of prematurity ? Results of a randomized controlled study. Pediatr Res 1993;34:675-9.

24 Carnielli VP, Da Riol R, Montini G. Recombinant erythropoietin in very-low-birth-weight infants. $N$ Engl $\mathcal{F}$ Med 1994;331:677

25 Montini G, Zacchello G, Perfumo F, et al. Pharmacokinetics and hematologic response to subcutaneous administration of recombinant human erythropoietin in children undergoing long-term peritoneal dialysis: A multicenter study $f$ Pediatr 1993;122:297-302.

26 Bechensteen AG, Haga P, Halvorsen S, et al. Erythropoietin, protein and iron supplementation and the prevention of anemia of prematurity. Arch Dis Child 1993;69:19-23.

27 Halperin DS, Wacker P, Lacourt G, et al. Effect of recombinant human erythropoietin in infants with the anemia of prematurity: a pilot study. 7 Pediatr 1990;116:779-86.

28 Meyer MP, Meyer JH, Commerford A, et al. Recombinant human erythropoietin in the treatment of the anemia of prematurity: Results of a double-blind, placebo-controlled study. Pediatrics 1994;93:918-23.

29 Brugnara C, Chambers LA, Mlynn E, Goldberg MA, Kruskall MS. Red blood cell regeneration induced by subcutaneous recombinant erythropoietin: Iron-deficient erythropoiesis in iron-replete subjects. Blood 1993;81:956Finch

30 Finch CA. Erythropoiesis, erythropoietin, and iron. Blood 1982;60:1241-6.

31 England JM, Ward SM, Down MC. Microcytosis, anisocytosis and the red cell indices in iron deficiency. $\mathrm{Br} F \mathrm{Hae}-$ matol 1976;34:589-93.

32 Conrad ME, Crosby WH. The natural hystory of iron deficiency induced by phlebotomy. Blood 1962;20:173-7.

33 Kinmond S, Aitchinson TC, Holland BM, Jones JG, Turner TL, Wardrop CAJ. Umbilical cord clamping and preterm TL, Wardrop CAJ. Umbilical cord clamping and
infants: a randomised trial. BMf 1993;306:172-5.

34 Pisacane A. Neonatal prevention of iron deficiency. BMF 1996;312:136-7.

35 Kivivuori SM, Heikinheimo M, Teppo AM, Siimes MA. Early rise in serum concentration of transferrin receptor induced by recombinant human erythropoietin in verylow-birth-weight infants. Pediatr Res 1994;36:85-9.

36 Beguin Y. The soluble transferrin receptor: biological aspects and clinical useulness as quantitative measure of erythropoiesis. Haematologica 1992;77:1-10.

37 Macdougall IC, Cavill I, Hulme B, et al. Detection of functional iron deficiency during erythropoietin treatment: a new approach. BMF 1992;304:225-6.

38 Sullivan JL. Iron, plasma antioxidants, and the oxygen radical disease of prematurity. Am $\mathcal{F}$ Dis Child 1988;142:1341- 